FRAGOSO, João; GUEDES, Roberto; KRAUSE, Thiago.

\title{
A América portuguesa e os sistemas atlânticos na época moderna: monarquia pluricontinental e Antigo Regime
}

Rio de Janeiro: Editora da Fundação Getúlio Vargas, 2013, v.1. 184p.

Helida Santos Conceição

Doutoranda, Programa de Pós-Graduação em Historia Social

Universidade Federal do Rio de Janeiro

Largo de São Francisco, s. 205, Centro, Rio de Janeiro, RJ, 20.051-070, Brasil

helidas@gmail.com

Nos últimos 20 anos a historiografia brasileira tem revisado o que se convencionou chamar de "modelos explicativos da economia colonial”, mais precisamente o sentido da colonização e a ideia de que a sociedade da América poderia ser traduzida em termos de latifúndio, monocultura e escravidão. O sentido teleológico contido nessa interpretação, formulada por Caio Prado Jr. na década de 1940, visava explicar a nossa dependência estrutural do capital externo, insistindo na ausência de uma economia interna e reduzindo a complexidade da sociedade que se formou no novo mundo às noções de exclusivismo colonial, pacto colonial e relação metropóle-colônia. Por essa perspectiva a sociedade colonial estava dividida basicamente entre senhores e escravos não havendo espaço para perceber historicamente outros agentes sociais.

Recebido 30 de outubro de 2014 | Aprovado 13 de dezembro de 2014

http://dx.doi.org/10.1590/0104-87752015000100015

Varia Historia, Belo Horizonte, vol. 31, n. 55, p. 303-306, jan/abr 2015 
O fato é que essa visão engessada do nosso passado colonial, não pode mais se sustentar em função dos novos direcionamentos da historiografia brasileira e da incontornável revisão teórica pela qual passou tais modelos explicativos. Por não sublinhar aspectos essenciais das sociedades que se formaram na América a partir de suas relações com as monarquias europeias, é que verificou- se a limitação desses modelos para analisar estas sociedades entre os séculos XVI e XVIII.

Atualmente diversos trabalhos desenvolvidos no âmbito das pós-graduações, vem estudando a América portuguesa nos termos de uma sociedade inserida no Antigo Regime. No entanto, faltava uma publicação que apresentasse essa discussão de modo direto, com uma linguagem factível e centrada não somente em novos aportes teóricos, mas chamando atenção para outras possibilidades de exploração de fontes documentais, tais como os assentos paroquiais e as fontes cartorárias, necessárias para uma apreensão mais complexa e relacional da dinâmica interna desta sociedade.

O livro A América Portuguesa e os sistemas atlânticos foi escrito por três historiadores ligados ao grupo de pesquisa Antigo Regime nos Trópicos, e cumpre um papel relevante para o desenvolvimento do conceito de monarquia pluricontinental, como uma hipótese de trabalho válida para estudar a monarquia católica portuguesa e a formação dos sistemas atlânticos. A obra está dividida em três capítulos, cada um dos quais articulados com a ideia da consolidação de um sistema atlântico em perspectiva comparada, com ênfase nas transformações socioeconômicas vividas pela América lusa entre os séculos XVI e XVIII. E, ao final, há um glossário, muito útil para os investigadores do tema, com os principais conceitos discutidos no texto.

O argumento principal é explorar como a produção e o excedente econômico estavam voltados para a reprodução interna da sociedade escravista com suas diferenças de status (sociedade estamental), atestados pela hierarquia social costumeira, através de um mercado regulado pela política. O conceito de monarquia pluricontinental, vale ressaltar, ainda em construção, tende a diferenciar-se do conceito de monarquia compósita formulado por J. Elliot para descrever a coroa Hispânica 
nos séculos XVI e XVII, muito embora ambas as monarquias ibéricas fossem católicas

Mesmo que apareçam similaridades, há que sublinhar que existiam diferenças consideráveis entre a monarquia compósita dos Austrias de Espanha e a pluricontinental lusa na gestão de suas possessões no novo mundo. Uma delas diz respeito a interação entre as elites reinóis e americanas nas formas de administração das populações nativas. A monarquia lusa vivia dos rendimentos auferidos nas conquistas, portanto possuia a centralidade na sua periferia, fatores que reiterariam a sua natureza sistêmica como uma monarquia pluricontinental. Para deixar ainda mais claro a formulação deste conceito, os autores analisam em perspectiva comparada as possessões ibéricas, com as colônias inglesas no Caribe, exploradas por uma racionalidade diferente, sob a influência das revoluções de 1640 e 1688, nas quais o lucro de proprietários absenteístas retornavam para suas praças europeias.

Dessa forma a monarquia portuguesa vista como Pluricontinental era também polissinodal e corporativa, orientada por uma disciplina social católica e modulada no interior da segunda escolástica. Baseados em estudos recentes, os autores atestam que nos territórios das conquistas, assegurou-se a autonomia das instituições com poderes concorrenciais, sobretudo no autogoverno dos municípios, orientados pelo princípio do bem comum e da economia das mercês. Tal situação inclusive havia se configurado em Angola, o que teria permitido a montagem do sistema atlântico luso do tráfico de escravos, uma vez que na monarquia pluricontinental as formas de governabilidade estavam alicerçadas em negociações e pactos políticos entre as elites locais e a administração do Império. A formação de vínculos de dependência/ lealdade, gerou uma visão de mundo, ou seja um ethos, que configurou-se como ligação incontornável entre sua majestade e o controle dos territórios das conquistas.

Esse sentimento de pertencimento à monarquia traduzia-se numa obediência amorosa, portanto consentida e voluntária, difundida através da disciplina social católica. De acordo com os autores, essa seria uma relevante chave interpretativa para o entender o funcionamento da 
economia no Antigo Regime católico. Nessa sociedade parte da riqueza social era comandada pelo além-túmulo, ou seja, a cada geração, uma parcela da riqueza social era transferida para instituições religiosas, retornando sob a forma de crédito que poderiam ser dispostos no mercado, possibilitando assim a reprodução da hierarquia social. Nesta realidade havia uma constante sociabilidade entre os diversos agentes - nobreza da terra, escravos, forros e pardos - que interagiam através de variados vínculos (parentais, compadrio, amizade, proteção) e agências necessárias à administração da república e do mercado.

A mobilidade social e a mestiçagem são também aspectos que deram o tom destas transformações ao longo do tempo, um indicativo disso segundo os autores é o aparecimento dos pardos como grupo social. A compilação de dados retirados de assentos paroquiais de duas principais freguesias do Rio de Janeiro são utilizados para demonstrar como esse grupo surge como resultado da interação coeva entre os indivíduos. Nesse sentido a oikonomia, entendida como economia doméstica, perfazia o lugar central da organização da hierarquia social, sendo a base que regulava o trabalho familiar e a escravidão, passando ao largo da interferência das leis de sua majestade.

A contribuição historiográfica deste livro não é totalmente inédita, uma vez que os conceitos já foram apresentados em outros trabalhos publicados pelo grupo de pesquisa Antigo Regime nos Trópicos. Ao final da leitura a questão que se coloca é sobre a pertinência de ampliarmos tal proposta teórica para outras áreas da América Lusa, sobretudo para vermos como diferentes configurações sociais se comportaram frente ao quadro teórico apontado pelos autores. 